\title{
Gobernar: The Journal of Latin American Public Policy and Governance
}

Volume 1 | Issue 1

Article 1

October 2017

\section{Table of Contents}

Follow this and additional works at: https://orb.binghamton.edu/gobernar

Part of the Comparative Politics Commons, Education Policy Commons, Latin American Studies Commons, Other Public Affairs, Public Policy and Public Administration Commons, Public Administration Commons, and the Public Policy Commons

\section{Recommended Citation}

(2017) "Table of Contents," Gobernar: The Journal of Latin American Public Policy and Governance: Vol. 1 : Iss. 1 , Article 1. Available at: https://orb.binghamton.edu/gobernar/vol1/iss1/1

This Table of Contents is brought to you for free and open access by The Open Repository @ Binghamton (The ORB). It has been accepted for inclusion in Gobernar: The Journal of Latin American Public Policy and Governance by an authorized editor of The Open Repository@ Binghamton

(The ORB). For more information, please contact ORB@binghamton.edu. 


\section{CONTENT / CONTENIDO}

Editorial

English-Español

Nadia Rubaii - Santiago Leyva-Botero

\section{Invited author // Autor invitado}

"Gobernar": una oportunidad para renovar la investigación en Administración Pública Comparada

Oscar Oszlak

\section{Articles // Artículos}

Los fundamentos del análisis prospectivo de políticas públicas Juan Guillermo Vieira Silva

El análisis de políticas públicas: la evolución de una disciplina Carlos Andrés Olaya Mesa

Identificando a los protagonistas: el mapeo de actores como herramienta para el diseño y análisis de políticas públicas Santiago Silva Jaramillo

Medios de producción y desarrollo productivo según Hugo Chávez (1999-2008) Josefina Bruni Celli - Javier Rodríguez

Biciactivismo en Medellín. De la acción colectiva a la agenda política Gloria Estela López Lopera - Diana Patricia Salinas Arango

Problemas y retos en la implementación del Gender Mainstreaming en la Política Pública de Mujeres de Medellín (2012-2015). Una lectura desde la meta-gobernanza Alejandra León Rojas

\section{Book review // Reseña}

Smart risks: How small grants are helping to solvesome of the world's biggest problems, by Lentfer and Cothran

Susan Appe 